\title{
Idiomy uniwersalizmu i imiona własne. Frank Stella a amerykański formalizm
}

Agnieszka Rejniak-Majewska 


\section{Idiomy uniwersalizmu i imiona własne. Frank Stella a amerykański formalizm}

Agnieszka Rejniak-Majewska

TEKSTY DRUGIE 2017, NR 4, S. 55-70

DOI: $10.18318 /$ td.2017.4.4

$\mathbf{Z}$ organizowana przez Muzeum Polin w Warszawie wiosną 2016 roku wystawa prac Franka Stelli z cyklu Polskie miasteczka (Polish Villages) stanowiła nie tylko okazję zobaczenia obok siebie znacznej części należących do tej serii obrazów, na co dzień rozproszonych w prywatnych i publicznych zbiorach, lecz także - ze względu na miejsce pokazu - skonfrontowania ich bliżej z dziedzictwem, do którego obrazy te mniej czy bardziej czytelnie się odnoszą. Monumentalne, abstrakcyjne shaped canvases, w sposób charakterystyczny dla tego amerykańskiego artysty oddziałujące przez swoje rzeźbiarskie, quasi-architektoniczne jakości, noszą tytuły odsyłające do „polskich miasteczek", sztetli dawnej Rzeczypospolitej, miejsc, w których niegdyś znajdowały się drewniane bożnice. Eunna Wola, Felsztyn, Odelsk, Olkienniki, Nasielsk, Grodno, Lanckorona, Bogoria, Zabłudów - to tytuły, które dla amerykańskich odbiorców musiały wyglądać i brzmieć obco i zagadkowo, a i dla polskiego odbiorcy niosą tyleż aurę bliskości - językowej swojskości, co nieznajomości i zapomnienia. Wydaje się jakby mapowały one jakieś nieznane terytorium,
Agnieszka Rejniak-Majewska - dr, historyk sztuki i estetyk, adiunkt $w$ Instytucie Filozofii Uniwersytetu Łódzkiego. Autorka książek Polityka doświadczenia. Clement Greenberg i tradycja formalistycznej krytyki sztuki (2017) oraz Puste miejsce po krytyce? Modernizm imaterialistyczna rewizja autonomii sztuki (2014). Współredaktorka - wraz z Tomaszem Majewskim i Wiktorem Marcem - tomu Migracje modernizmu. Nowoczesność i uchodźcy (2014). Kontakt: agnesmarej@wp.pl 
przy czym poczucie konkretności wskazywanych w nich miejsc opiera się raczej na ewokacyjnej sile nazw własnych niż na faktycznej wiedzy.

Sens tych tytułów, trudny do uchwycenia na płaszczyźnie czysto wizualnego odbioru prac Stelli, w ramach warszawskiej wystawy został jasno skonkretyzowany przez zestawienie cyklu z archiwalną dokumentacją synagog, opisanych w albumie Marii i Kazimierza Piechotków Wooden Synagogues książce, której anglojęzyczne wydanie stało się dla Stelli w 1970 roku punktem wyjścia do powstania całego cyklu. Historia opracowywania w Polsce w latach 20. i 30. architektonicznej dokumentacji synagog oraz wydanej po wojnie na podstawie zachowanych dokumentów publikacji Piechotków, będącej upamiętnieniem utraconej architektury, została spleciona z narracją rozwijaną przez same obrazy Stelli, ich kolejne warianty i poświęcone im komentarze'. Miejsca, do których w swoich tytułach odnosił się Stella, zidentyfikowano z poszczególnymi opisanymi przez Piechotków budynkami, których fotografie i rysunki architektoniczne znalazły się na wystawie. Ten sposób rozszyfrowania i rozpisania cyklu według katalogu nazw miejscowości nie niwelował jednak poczucia obcości dzielącej stare fotograficzne zapisy czy wykonane z pietyzmem architektoniczne pomiary i rysunki od powstałych kilkadziesiąt lat później, modernistycznych, abstrakcyjnych obrazów. Mimo odniesień obecnych w tytułach prac Stelli oraz w ich formalnej strukturze - budzącej skojarzenia z drewnianymi konstrukcjami i złożonym geometrycznym rysunkiem stropów, a jednocześnie z formą zdestruowaną i pozbawioną funkcji, jego dzieła sprawiają wrażenie autonomicznych, zamkniętych w sobie całości. Raczej re-konstruują one w sobie formy zniszczonej architektury, niż cokolwiek tu ilustrują. Można by traktować je jako samoistne, pozbawione referencji dzieła malarskie, gdyby nie ich tytuły te zaś tyleż odnoszą je do konkretnego miejsca, czynią je pamiątką czy nośnikiem danego obiektu, co przez ów efekt odsyłania wzmagają świadomość nieobecności i braku. Autorzy wystawy umiejętnie wykorzystali to oddziaływanie, tworząc jednocześnie opowieść o istniejącej niegdyś architekturze, pracy jej badaczy, jak i o konstrukcyjnej a zarazem mnemonicznej pracy Stelli. Widz, który spotkałby się z tymi obrazami amerykańskiego artysty w innych okolicznościach, aby je zrozumieć, musiałby zapewne znać lub dopowiedzieć sobie tę całą historię. Tytuły są tu subtelnym odesłaniem albo - przez swoją niejasność - pytaniem, w każdym razie trudnym do pominięcia aspektem

1 Frank Stella i synagogi dawnej Polski, katalog wystawy, red. A. Tanikowski, Muzeum Historii Żydów Polskich Polin, Warszawa 2016. 
tego malarstwa. Tytuł - jako pozornie oderwane słowo lub fraza, jest w stanie przerzucić naszą uwagę daleko poza to, co bezpośrednio dane, zmieniając nasze postrzeganie. Rola tytułów jako paratekstów ukierunkowujących lub przeciwnie - komplikujących odbiór obrazu, określających charakter komunikacyjnej relacji z odbiorca, pozostaje - w szczególności w odniesieniu do malarstwa abstrakcyjnego, kwestią wartą odrębnych analiz. Całą historię amerykańskiego abstrakcjonizmu, od Pollocka po minimalizm, można by spróbować prześledzić pod kątem zmieniających się poetyk nadawanych pracom tytułów ${ }^{2}$.W tym miejscu nie podejmuję się tak szerokiego zadania; skupię się jedynie na kilku obrazach Stelli oraz towarzyszących im interpretacjach. Pytanie, dlaczego pewne tytuły - w tym tytuły prac składających się na Polish Villages ${ }^{3}$ - przez długi czas były ignorowane, to pytanie zarówno o ogólne presupozycje co do funkcji i znaczenia tytułów, zwyczajowo redukowanych do roli nic niemówiących, identyfikacyjnych etykiet, co pytanie o warunki widzialności i czytelności określonych odniesień. O ile przeważającą przez długo obojętność wobec tytułów prac Stelli łatwo złożyć na karb nawyków formalistycznej krytyki - niechętnej wobec zanieczyszczającej sztuki plastyczne „literatury”, to przez pryzmat tych jednostkowych przemilczeń można też inaczej spojrzeć na uwarunkowania modernistycznej krytyki.

\section{Niewidzialne słowa}

Choć znaczenie prac Stelli wykracza, jak sądzę, poza horyzont formalistycznych odczytań, należy zaznaczyć, że stosunek artysty do formalizmu nigdy nie polegał na prostym antagonizmie. Zdaniem niektórych autorów on sam w swoich poglądach na malarstwo kwalifikuje się po dziś dzień jako uparty formalista ${ }^{4}$. Kariera Stelli nie tylko rozpoczynała się pod skrzydłami formalistycznej krytyki, ale pozostawał on akolitą jej wiodących autorów. Podobnie jak wielu młodych artystów, poznawszy w 1958 roku Clementa Greenberga, Stella był pod wrażeniem jego koncepcji ${ }^{5}$, w pełni identyfikując

2 Por. S. Rich Bridging the Generation Gaps in Barnett Newman's 'Who is Afraid of Red, Yellow, and Blue?', "American Art" 2005 Vol. 19, No. 33, s. 17-19, 32.

3 M. Godfrey Frank Stella's Polish Village series, w: tegoż Abstraction and the Holocaust, Yale University Press, New Haven, Conn. 2007, s. 92.

4 T.R. Quigley Ortodox Formalism and the Metaphysics of Pictorialism, "The Kenyon Review” 1987 Vol. 9, No 4, s. 147-148.

5 M. Fried Art and Objecthood. Essays and Reviews, Chicago-London 1998, s. 4-5. 
się z przekonaniem, że rzeczowe, zdystansowane myślenie o sztuce w kategoriach formalnych rozwiązań jest wobec niej najbardziej właściwą postawą. Greenberg umieścił go w ramach promowanego przez siebie nurtu „pomalarskiej abstrakcji", definiowanego w opozycji do gesturalności i egzystencjalnej retoryki abstrakcyjnego ekspresjonizmu ${ }^{6}$. Stella pozostawał też w latach 60. kluczowym bohaterem pozytywnym w pismach Michaela Frieda, wiernego kontynuatora greenbergowskiej metody, z którym od czasów studiów łączyły go przyjacielskie stosunki. Podkreślane przez Stellę przeświadczenie o „czysto wizualnym" znaczeniu prac wyrastało wyraźnie z pokrewnej im perspektywy. Mimo to słynne twierdzenie Stelli „to, co widzisz, jest tym, co widzisz"' należy, jak sądzę, odczytywać w innym duchu, nie jako wyrażoną w potocznym języku wersję formalistycznego ideału czystej optyczności, co wyraz antyhermeneutycznego nastawienia i przywiązania do bezpośredniego, konkretnego doświadczenia. W konkretystyczną postawę Stelli od początku wkradała się bowiem pewna doza ironii i przekory, kiedy swoim abstrakcyjnym obrazom nadawał figuratywne tytuły, takie jak Portret Michaela Frieda stojacego na głowie nad Cayuga Waters (1959) ${ }^{8}$, Jasper's Dilemma (1962) - co było czytelną wówczas aluzją do płócien Jaspera Johnsa, lub kiedy swoje shaped canvases utrzymane $\mathrm{w}$ formach podstawowych figur geometrycznych przedstawiał jako szereg portretów (Portrait series, 1963), rozpisując je na nazwiska znajomych: imię Carla Andre przypisane zostało do obrazu o kształcie leżącego rombu, natomiast Hollisa Framptona miało reprezentować płótno w kształcie pustego kwadratu. Arbitralność i na poły prywatny charakter tych odniesień pozwalały traktować je jako rodzaj niezobowiązującej towarzyskiej zabawy, żartu nadpisanego nad istotnym sensem malarskich wyborów, których znaczenia krytyka upatrywała w sposobie podejścia do malarskiej materii w surowej rzeczowości, antyiluzjonizmie i akcentowaniu fizyczności podłoża. Między swobodą zawartych w tytułach odniesień - bliską ówczesnym

6 Deklaracją tego nurtu była zorganizowana przez Greenberga wystawa „Post-Painterly Abstraction" w Los Angeles County Museum of Art w 1964 roku, do której włączył on prace Stelli. Por. C. Greenberg Post-Painterly Abstraction, w: The Collected Essays and Criticism, ed. by J. O'Brian, vol. 4, University of Chicago Press, Chicago-London 1993, S. 192-197.

7 B. Glaser Questions to Stella and Donald Judd (wywiad opublikowany w "Art News" 1966 Vol 65, No.5), przedruk w: Theories and Documents of Contemporary Art. A Sourcebook of Contemporary Artists'Writings, ed. by K. Stiles, P. Selz, University of California Press, Berekely-Los AngelesLondon 1996, s. 121. 
eksperymentom poetyckim Carla Andre i filmowym działaniom Framptona ze słowem znalezionym i materią werbalnego zapisu - a formalistycznym definiowaniem malarstwa przez pryzmat czysto stylistycznych wartości i innowacji, rysowała się jednak rozbieżność, najbardziej jaskrawo uwidoczniona w recepcji serii Black Paintings (1958-1960).

Cykl ten, już w 1959 roku zakupiony przez Alfreda Barra do kolekcji MoMA, przyjęło się traktować jako wzorcowy przykład wczesnego stylu artysty. Obecnie jednak tym, co szczególnie przyciąga uwagę do tego cyklu, są tytuły trzech spośród 15 składających się nań obrazów: Die Fahne Hoch, Arbeit Macht Frei i Reichstag. Owe zaskakujące i prowokacyjne odniesienia do faszystowskiej przeszłości mogą się dziś jawić - jak pisała Lisa Saltzman w kontekście wystawy Mirroring Evil: Nazi Imagery/Recent Art (Jewish Museum, 2002) - jako „kontrpropozycja dla nowojorskiej szkoły malarstwa, unikającej poruszania kwestii historycznych" i jako zapowiedź zmiany w ówczesnej kulturze reprezentacji'. O ile w swojej estetycznej bezosobowości i monotonii Czarne malowidła już od momentu powstania uderzały odbiorców swoją nihilistyczną pustką i „brakiem emocji”"10, ukazując się - jak komentuje Saltzman - jako rodzaj „epitafiów dla konającego powojennego abstrakcjonizmu"11, to dołączone do nich tytuły musiały dodatkowo działać jako nieoczekiwany przebłysk obcości, sygnał realnego, kwestionujący poczucie samoistności i samowystarczalności malarskich reguł. Saltzman, odwołując się do tych tytułów, widzi w nich znak końca wysokiego modernizmu i jego założeń o autonomii sztuki - transgresyjny gest otwierający możliwość „skonfrontowania się z historyczną spuścizną faszyzmu i ludobójstwa"12. Jeszcze dalej idzie w swojej interpretacji Benjamin Buchloh, w repetytywnych układach czarnych pasów

9 L. Saltzman Awangarda i kicz raz jeszcze. O etyce reprezentacji, przeł. K. Bojarska, "Literatura na Świecie" 2004 nr 1/2, S. 208-209.

B. O'Doherty Frank Stella and a Crisis of Nothingness, "New York Times" 19.01.1964, s. 21 http://www.nytimes.com/1964/01/19/frank-stella-and-a-crisis-of-nothingness.html?_r=0 (11.05.2016).

11 Obrazy te prowokują podobne figuratywne określenia. Peter Schjeldahl opisałje jako "nagrobki abstrakcyjnego ekspresjonizmu”. P. Schjeldahl Big Ideas. A Frank Stella retrospective, "The New Yorker" 9.11.2015, s. 84. Gest dystansowania się od malarstwa gestu był podkreślany niemal od początku przez piszących o tych obrazach krytyków. Philip Leider stwierdził, że ich „chłodna, pozbawiona humoru metodyczność" była "policzkiem” wymierzonym w abstrakcyjny ekspresjonizm. P. Leider Literalness and Abstractness. Frank Stella's Retrospective , Artforum” 1970 Vol. 8, No. 8, s. 45 . 
Stelli upatrując sarkastycznego zobrazowania modernistycznej „episteme zamknięcia i kontroli", a w towarzyszących im tytułach - ironicznego wskazania, że „modernistycznej abstrakcji nie sposób nie skojarzyć z historią totalitarnej destrukcji" i że historię sztuki abstrakcyjnej powinno się oceniać pod kątem „jej udziału w zaprzeczaniu i skrywaniu owej destrukcji”’3. W ten sposób w oczach Buchloha Stella staje się - nie do końca zapewne świadomym - demaskatorem modernistycznej abstrakcji i totalitarnych aspektów nowoczesności.

Sarkazm tej interpretacji uderza oczywiście w domknięte, pełne samozadowolenia narracje modernizmu, jakich było wiele w utrwalonych wykładniach amerykańskiej sztuki. Niemniej trudno oprzeć się wrażeniu, że Buchloh powtarza w tym miejscu znane, wielokrotnie stawiane wobec nowoczesności oskarżenia, a tytuły Stelli są tylko punktem zaczepienia dla uprzedniej już tezy. Choć taki interpretacyjny użytek z jego prac nie jest bezpodstawny i nieuprawniony, to nie uwzględnia on płynności i chwiejności podsuwanych przez Stellę znaczeń i zasobu toposów i toponimów, dołączonych do abstrakcyjnych Black Paintings. Tytuły pozostałych prac z serii, takie jak The Marriage of Reason and Squalor, Bethlem Hospital, Tomlinson Park Court, Arundel Castle, Club Onyx, jak wskazała Brenda Richardson, w większości odnosiły się do konkretnych miejsc i budynków, mniej czy bardziej związanych z biografią artysty. W sumie rysowały one dość ponurą mapę Nowego Jorku i nowoczesnego miasta, dopełniając literalną czerń płócien siatką indywidualnych skojarzen' ${ }^{14}$. Wybór „nazw znalezionych", niczym znalezionych obiektów gotowych (readymade), ograniczał jednak grę subiektywnych, metaforycznych znaczeń, podkreślając w zamian ich chłodną rzeczowość. Owa prozaiczna konkretność mogła się jawić jako zaprzeczenie psychologicznej i emocjonalnej głębi, sugerowanej w bardziej poetyckim języku tytułów abstrakcyjnego ekspresjonizmu. Czerpiąc z języka obiegowych nazw i publicznej przestrzeni,

B. Buchloh Painting as Diagram. Five Notes on Frank Stella's Early Paintings, 1958-1959, "October" 2013 Vol. 143, S. 139.

14 B. Richardson Frank Stella: The Black Paintings, Baltimore Museum of Art 1976, s. 26. Jak objaśnia Richardson, Tomlinson Park Court i Arundel Castle to miejsca, gdzie Stella miał okazję przygodnie pracować jako malarz ścienny; Club Onyx, Seven Steps to nazwy klubów gejowskich, kojarzonych z gorszymi częściami Nowego Jorku. Z kolei Bethlem Hospital to znana nazwa londyńskiego szpitala dla psychicznie chorych, utrwalona w literaturze i w filmie. Tytuł The Marriage of Reason and Squalor można odbierać jako aluzję zarówno do nędznych warunków życia samego artysty, jak i do miejskiego otoczenia, oraz jako grę z The Marriage of Heaven and Hell Williama Blake'a. 
Stella łączył właściwą im zewnętrzność i bezosobowość z efektem przygodności prywatnych skojarzeń. Częścią tej mentalnej włóczęgi były najwyraźniej także użyte przez niego odniesienia do faszyzmu - nazistowskich flag, pieśni i zobaczonych w telewizji scen z Parteitagów, zapadających w pamięć nie jako gotowe znaczenia, a naładowane ciemną energią obrazy. W rozmowie z Williamem Rubinem Frank Stella przyznawał, że wrażenie, jakie wywarła na nim estetyka władzy totalitarnej, powróciło w trakcie pracy w skojarzeniu $\mathrm{z}$ wyglądem czarnych obrazów ${ }^{15}$. Trudno zatem traktować te tytuły jako całkowicie przypadkowe, zewnętrzne znaki, pozbawione istotniejszego znaczenia (jak sugerował Rubin, podkreślając prywatny charakter stojących za nimi skojarzeń), ale nie powinno się też - zgodnie z uwagą samego Stelli - szukać w nich klucza, który wskazywałby na jakąś ukrytą w obrazach treść (dosłownie Stella stwierdzał, że nie należy ich traktowć jako „poręcznego uchwytu” ${ }^{16}$. Zamiast wewnętrznej przynależności znaku i znaczenia, zmysłowej postaci i ukrytej treści, działa tu zasada przyległości i zewnętrzności, horyzontalnych powiązań, pozbawionych organizującego i spajającego centrum.Niezależnie od trudności, które niesie taka forma znaczenia, uwaga, jaką współcześni interpretatorzy poświęcili tytułom Black Paintings, pozostaje w kontraście wobec całkowitej „niewidoczności” tych tytułów w pierwotnym odbiorze. Wpisanie prac Stelli w ciągłą, logicznie uporządkowaną narrację na temat rozwoju abstrakcyjnego malarstwa wymagało pominięcia tytułów, które odsyłając do pamięci nazizmu, kazałyby się zatrzymywać w jakimś trudnym do przejścia, niezrozumiałym punkcie. „Przymykanie oka” na towarzyszące tym obrazom słowa było przez długi czas dominującą strategią wystawiających je instytucji i piszących o nich krytyków. Obraz Die Fahne Hoch był wielokrotnie pokazywany i reprodukowany razem z podpisem, lecz nikt nie pytał o jego sens. Jego reprodukcje wybierano do książek i katalogów, najwyraźniej ze względu na efektowną wizualnie i zapadającą w pamięć kompozycję linearnych podziałów - pionową i opartą na układzie krzyża - dzięki której mógł on figurować jako pars pro toto całego cyklu. Uwaga komentatorów koncentrowała się wyłącznie na swoistości formalnych rozwiązań Stelli, które Carl Andre - notabene w słowach zamieszczonych obok reprodukcji tego właśnie obrazu - opisywał w buńczucznym tonie: „Sztuka wyklucza to co niekonieczne. Frank Stella uznał za konieczne by malować pasy. W obrazach tych nie ma nic więcej. [...] Symbole to wymieniane między ludźmi liczmany. Malarstwo Franka Stelli nie

15 W. Rubin Frank Stella, Museum of Modern Art, New York 1970, s. 44.

16 Tamże, s. 46. 
jest symboliczne. Jego pasy to ścieżki pędzla na płótnie. Ścieżki te prowadzą tylko do malarstwa"17. O ile poetyka komentarza Andre uwypuklała wspólną im obu, dwuznaczną postawę milczenia i wycofania, formalistyczna krytyka pochylała się nad pasami Stelli z ufnością i dobrą wiarą, jak gdyby w ich regularnych układach widziała prostą drogę do nowego malarstwa i nowych, czysto malarskich doświadczeń. W tekście towarzyszącym retrospektywnej wystawie Stelli w 1970 roku w Londynie kurator John McLean pisał na temat Black Paintings: „W swoim zróżnicowanym układzie jego pasy powtarzają horyzontalne, wertykalne lub diagonalne osie prostokąta, tak iż wzmacniają poczucie dwuwymiarowości i symetrii płaszczyzny. Sugerują one możliwość przedłużania poza ograniczeniem płaszczyzny. Wzmacnia to wrażenie otwartości obrazów, przestrzennego rozmachu, który stał się znakiem progresywnej sztuki amerykańskiej"18.

Znamienne, że Czarne malowidła, choć zgodnie uznawane za ważny etap w twórczości artysty, w ramach retrospektywnych analiz były rzadko rozpatrywane jako odrębna całość. Michael Fried, który wiele miejsca poświęcił dociekaniom nad specyfiką oddziaływania obrazów Stelli, pisał o tym cyklu jedynie w odniesieniu do tego, co nazwał „dedukcyjną strukturą" (deductive structure) obrazu - to znaczy zastosowanej tu po raz pierwszy tak konsekwentnie przez Stellę zasady organizowania kompozycji na podstawie wariacji kształtów „wydedukowanych” z kształtu obrazu, czyli wyprowadzonych z układu krawędzi blejtramu wypełniających płaszczyznę równoległych pasów. W perspektywie Frieda był to niejako wstęp do dalszych wariantów stripe paintings i późniejszych shaped canvases - w ten sposób czerń i potencjalnie złowieszcze skojarzenia Black paintings zostały przesłonięte w proponowanym przezeń opisie przez późniejsze, bardziej barwne i zróżnicowane obrazy. William Rubin, choć serii tej poświęcił więcej miejsca, zwracając uwagę na dojmujące działanie czerni, surową symetrię $\mathrm{i}$ „heraldyczną obecność" obrazów ${ }^{19}$, również skupił się przede wszystkim na osadzeniu ich w ramach dłuższej tradycji amerykańskiego malarstwa - twórczości Pollocka, Rothki, Newmana. O ile odejście od „romantycznych" rysów abstrakcyjnego ekspresjonizmu dzieliło jego zdaniem Stellę od jego poprzedników, to wybór dużej skali obrazów, bezpośredni stosunek do płaszczyzny obrazowej, wreszcie - widoczne

C. Andre Preface to Stripe Paintings, w: Sixteen Americans, ed. by D. Miller, Museum of Modern Art, New York 1959, s. 76. 
ślady manualnego wykonania, według Rubina nadal miały odróżniać jego płótna od europejskiej tradycji geometrycznej abstrakcji, czyniąc go kontynuatorem amerykańskiej szkoły malarstwa ${ }^{20}$.

\section{Podwójny dyskurs amerykańskiej abstrakcji}

Tego rodzaju formalistyczny sposób myślenia, z jego uporządkowaną, linearną wizją rozwoju sztuki był, jak wiadomo, skutecznym narzędziem propagandowego sukcesu powojennej sztuki amerykańskiej. Powielanie go we wszelkich możliwych kontekstach niewątpliwie przyczyniło się dodatkowo do jego banalizacji. Uniwersalizujący język opisów, operujący na poziomie wizualnej ewidencji i stylistycznych porównań, pozwalał rozpatrywać amerykańską sztukę na równi z europejskim modernizmem, przezwyciężając dawniejsze poczucie jej prowincjonalizmu. W istocie jednak dyskurs ten stanowił idiom typowo amerykański, nie tylko ze względu na fundujące go empiryczne nastawienie, ale przez akcentowanie typowo amerykańskich wartości, takich jak pewność i śmiałość działania, powiązanie spontaniczności i samokontroli. Doświadczenie wojennej destrukcji jako moment załamania i kryzysu nowoczesności nie miało do tej narracji dostępu - co wyraźnie uwidoczniły interpretacyjne losy Black Paintings, i nie tylko one ${ }^{21}$. W stworzonym przez Clementa Greenberga obrazie rozwoju modernistycznej sztuki nie pojawia się w gruncie rzeczy refleksja nad znaczeniem Zagłady i wojny. W wykładni tej podstawowym, pilnie strzeżonym założeniem pozostawała teza o wewnętrznej autonomii i ciągłości rozwoju form. Rozdzierająca, nadmiarowa ekspresja, w której Greenberg rozpoznawał echa wojennego koszmaru i przerażenia, była przez niego traktowana jako coś spoza sztuki, co przeczy artystycznej „jakości”.

Postawy twórców, także tych opowiadających się po stronie abstrakcji, były w tej materii bardziej złożone. Niektórzy, najdobitniej Barnett Newman, nie godzili się na tego rodzaju estetyczne zamknięcie, twierdząc, że po II wojnie światowej nie ma już drogi powrotnej do „raju czystych form”,

20 Tamże, s. 34-40.

21 Podobnie zmarginalizowany i nie-odczytany został cykl Morrisa Louisa Charred Journal: Firewritten (1951), który, jak przekonuje Mark Godfrey, nie powinien być traktowany jako kolejny przykład malarstwa gestu, lecz interpretowany przez odniesienie do pisma, do nazistowskiego palenia ksiąg („zwęglenie”, o którym mówi tytuł i które wizualne sugerowane przez warstwę czerni kryjącej inną barwę pigmentu), jak i do białego ognia Tory. Godfrey Abstraction and Holocaust, s. 23-50. 
że sztuka „musi coś mówić”22. Mimo jednak obecnych w pisarskich wypowiedziach Newmana odwołań do Holokaustu, w jego pracach nie pojawiały się równie czytelne odniesienia. W 1945 roku, w czasie kiedy do publicznego obiegu, do prasy i kin trafiły filmy i fotografie z wyzwolonych nazistowskich obozów, Newman napisał krótki tekst Surrealism and the War, w którym wojenne potworności przedstawiał jako urzeczywistnienie wizji z płócien surrealistów: „Nie istnieje malarstwo, które byłoby bardziej surrealistyczne niż fotografie niemieckich zbrodni [...] Sadyzm tych obrazów, ich okropieństwo i patos są wokół nas" ${ }^{\prime 23}$. Wobec bezpośrednich świadectw malarskie próby przedstawienia czegokolwiek musiały zdaniem Newmana pozostać czymś nieistotnym - surrealistyczne sny zostały pochłonięte przez rzeczywistość, a sama ta rzeczywistość została skazana na nieprzedstawialność.

Opozycji między autonomizmem abstrakcji a wrażliwością na katastrofę nie da się zatem sprowadzić do prostego przeciwieństwa między narzuconą formalistyczną interpretacją a artystyczną praktyką. Estetyka niewyrażalności, znajdująca wyraz w abstrakcyjnym ekspresjonizmie i w postawie Newmana, kazała szukać istotnego znaczenia nie w sferze ikonografii, lecz na płaszczyźnie gestu, czystej ekspresji, wolnej od partykularnych przedmiotowych odniesień. Stacje drogi krzyżowej: Lema Sabachthani (1958-1966) Newmana, choć ze względu na przywołanie słów Jezusa zdawały się zawierać aluzję do żydowskiego losu, lokowały to odniesienie na najbardziej ogólnym, uniwersalnym poziomie. Tytuły Newmana, takie jak Be, Onement, Who's afraid of Red, Yellow, and Blue?, akcentowały przede wszystkim jednostkowość obrazu i wyjątkowość czy wręcz konfrontacyjny charakter spotkania z nim. Newman sprzeczał się z Greenbergiem w kwestii opisów swoich obrazów, nie zaakceptował też, by określono go mianem formalisty (odrzucił zaproszenie do wystąpienia na wystawie zatytułowanej „Formalists” w 1963 roku w Gallery of Modern Art w Waszyngtonie). Mimo to jednak zgadzał się z generalną charakterystyką nowego malarstwa, zawartą w tekstach Greenberga - kładącą nacisk na poczucie nieiluzjonistycznej, bezpośredniej obecności „tu i teraz", na oddziaływanie samej płaszczyzny i malarskich środków. W powściagliwym odrzuceniu subiektywnych emocji i osobistych skojarzeń, w niechęci do zawężających narodowych i etnicznych klasyfikacji, Newman stał po tej

Knopf Publishing, New York 1990, s. 105.

23 B. Newman Surrealism and the War, w: Selected Writings, s. 95. 
samej stronie co Greenberg - w podobny sposób obydwaj szukali w doświadczeniu sztuki przestrzeni uniwersalnej, pozwalającej wykroczyć poza partykularną tożsamość, a w każdym razie przełożyć ją na uniwersalną formę ekspresji.

Podwójność - między zacierającą różnice, uniwersalistyczną wizją nowoczesnej abstrakcji, uwolnionej od ciężaru historii, a świadomością żydowskiego doświadczenia i tożsamości, nie była więc prostą podwójnością między narzuconą formalistyczną interpretacją a artystyczną praktyką - była wpisana w postawy samych artystów, w przypadku Greenberga zaś można, jak sądzę, uznać ją za wewnętrzny warunek formalistycznej koncepcji sztuki. W pisarstwie Greenberga, który swoją krytyczną działalność zaczynał - o czym rzadko się pamięta - od komentarzy poświęconych literaturze, istniała wyraźna dwutorowość podział między jego tekstami dotyczącymi żydowskiej literatury i problematyki polityczno-społecznej, w których żydowskie doświadczenie i związane z nim konflikty miały swoją artykulację, a obszarem sztuk wizualnych, gdzie to, co rozumiał on przez pojęcie wielkiej tradycji (major art) - i co było stawką jego krytycznych ocen - Greenberg definiował zawsze w opozycji do "sztuk pomniejszych" (minor art) - podporządkowanych konkretnym społecznym potrzebom, oraz tego wszystkiego co uważał za zapóźnione, wtórne czy prowincjonalne. Przynależność do wielkiej tradycji - będącej w istocie przedłużeniem kanonicznego dziedzictwa sztuki francuskiej i włoskiej, zakładała wyjście poza własny kulturowy partykularyzm. W istocie, jak podkreślała m.in. Margaret Olin, było to oczekiwanie typowe dla intelektualistów i twórców żydowskich, którzy w zuniwersalizowanej koncepcji sztuki, istniejącej niezależnie od narodowych i etnicznych podziałów, szukali drogi kulturowej asymilacji i podstawy własnej nowoczesnej tożsamości² ${ }^{24}$ Greenberg rzadko i na ogół niechętnie pisał o artystach zaznaczających swój związek z tradycją żydowską; w twórczości Chagalla, którą skądinąd doceniał ze względu na jej czysto malarskie wartości, drażniło go "czynienie widowiska z własnego wschodnioeuropejskiego żydostwa, jako czegoś egzotycznego i malowniczego" ${ }^{25}$. Niechęć do akcentowania żydowskiej odrębności wiązała się tu - podobnie jak u twórców abstrakcyjnego ekspresjonizmu, z których wielu miało żydowskie korzenie - z obawą przed

24 M. Olin The Nation without Art. Examining Modern Discourses on Jewish Art, University of Nebraska Press, London 2001, s. 161-162, 171.

25 C. Greenberg Two of the Moderns: Review of "Chagall" by Jacques Lassaingne and "Soutine" by Raymond Cogniat, w: Collected Essays, vol. III, s. 159. 
gettoizacją (Barnett Newman wyrażał swoje oburzenie wobec terminu „sztuka żydowska", nawet gdy stosowano je w formie pytajnej ${ }^{26}$ ), ale też z oporem wobec izolacjonistycznych postaw, które Greenberg oceniał jako „żydowski szowinizm". W artykule Self-Hatred and Jewish Chauvinism (1950) Greenberg przekonywał, że choć „wszystko w naszej [żydowskiej] historii mogłoby uzasadniać szaleńczy nacjonalizm", i choć zwrot w stronę mocnej kolektywnej identyfikacji musiał być reakcją na pamięć żydowskiej przeszłości i Zagładę to powrót do zwartej narodowej i kulturowej tożsamości, wybór „pozytywnej żydowskości" (positive jewishness) oznaczałby odebranie sensu wielowiekowej historii żydowskiej diaspory, stanowiłby ograniczenie dla wolności indywidualnych wyborów. Osobiste uznanie kondycji wykorzenienia okazywało się w tym ujęciu szansą jednostkowej emancypacji. Diasporyczna żydowska tożsamość - z konieczności podzielona, zawieszona między niemożnością komfortowego zadomowienia we własnej tradycji a niemożliwością pełnej asymilacji - spotykała się jego zdaniem z charakterystycznym dla nowoczesności doświadczeniem wykorzenienia i alienacji - i w tym Greenberg upatrywał jej uniwersalistycznego wymiaru. Możliwość odnalezienia się w głównym nurcie nowoczesnej, awangardowej sztuki (której pozornie nic nie łączyło z żydowską przeszłością) była sposobem przełożenia własnej pozycji obcości na bardziej uniwersalne znaczenie ${ }^{27}$. Owo założenie o wewnętrznej korespondencji nowoczesnej żydowskiej tożsamości i sztuki abstrakcyjnej, wraz z niechęcią do zaznaczania etnicznej odrębności, zgadzało się z przeważającym w latach 50. i 6o. nastawieniem artystycznych środowisk i z polityką nowojorskiego Jewish Museum, otwartego na nowe tendencje artystyczne i twórczość nieżydowskich artystów ${ }^{28}$. To pokrewieństwo z wyboru w dosadny sposób podkreślał Leo Steinberg w katalogu zorganizowanej w Jewish Museum wystawy drugiego pokolenia szkoły nowojorskiej. Szukając związków między żydowską tradycją a artystyczną nowoczesnością, Steinberg nie tylko przywołał biblijny zakaz przedstawień, ale skoncentrował się na współczesności: „Naród żydowski i sztuka abstrakcyjna to w równym stopniu mistrzowie wyrzeczenia; odrzuciwszy wszelkie rekwizyty, na których zdawało się polegać istnienie narodu, Żydzi przetrwali jako abstrakcyjny

26 M. Godfrey Abstraction and the Holocaust, s. 52-53.

27 Por. M. Olin The Nation without Art, s. 174.

28 Frank Stella parokrotnie uczestniczył w tym czasie wystawach organizowanych w Jewish Museum: „Towards a New Abstraction" (1963), "Black and White” (1963) i „Primary Structures” (1966). 
naród, dowodząc, podobnie jak sztuka abstrakcyjna, bez jak wielu rzeczy można się obyćn"

O ile w Greenbergowskiej wykładni nowoczesnego malarstwa nie było miejsca na dylematy związane z żydowską pamięcią i tożsamością, całkiem inaczej rzecz się miała w przypadku literatury. W komentarzach na temat pisarstwa żydowskich autorów Greenberg zwracał uwagę na kondycję społecznej i kulturowej marginalności, na literackie sposoby radzenia sobie z nią i nieodłączne od tego zmagania z językiem. Pisząc o dziele Kafki, podkreślał zarówno jego złożoną relację do utraconej judaistycznej tradycji i do otaczającej mieszczańskiej rzeczywistości, jak i stosunek do niemczyzny i jej literackiej spuścizny - dręczące poczucie nieadekwatności języka. „Wydaje się, że to, co Kafka chciał przekazać - stwierdzał Greenberg - przekraczało literaturę, i gdzieś głęboko, wbrew jemu samemu, sztuka wydawała mu się płytka, a w każdym razie zbyt niepełna, by mogła być czymś doniosłym w porównaniu z rzeczywistością””0 Ów „radykalny sprawdzian" doświadczenia, kwestionujący ustalone granice sztuki, decydujący o immanentnej trudności tworzenia, Greenberg postrzegał w tym przypadku jako wyznacznik literackiej nowoczesności ${ }^{31}$.

W odniesieniu do malarstwa Greenberg i kontynuatorzy jego formalistycznej metody nie starali się jednak na podobnej zasadzie uchwycić zależności malarskiej ekspresji od jej społeczno-kulturowego usytuowania. Wynikało to zapewne z przekonania, że literatura i sztuki wizualne to całkiem odrębne modalności wyrazu - o ile literatura, której tworzywem jest język, pozostaje nieodłącznie związana z kulturowym kodem danego języka, sytuowaniem się w nim i komunikowaniem pewnej wizji rzeczywistości, medium malarstwa cechować miała zakorzeniona w doświadczeniu wzrokowym uniwersalność i autonomia. Akcentowanie autonomii sztuk wizualnych i ich odrębnej logiki rozwoju było zarazem sposobem podkreślenia ich niezależności od tradycyjnie górującej nad nimi i obdarzonej wyższą kulturową rangą literatury. W tym kontekście tytuły obrazów pomijano nie tylko jako pozawizualny, zewnętrzny dodatek, nieistotny z punktu widzenia artystycznej wartości, ale również ze względu na nieprzydatność w określeniu

29 L. Steinberg Artists of the New York School: Second Generation, Jewish Museum, New York 1957. Cyt. za M. Raphael Judaism and the Visual Image: A lewish Theology of Art, London-New York 2009, s. 40.

C. Greenberg The Jewishness of Franz Kafka: Some Sources of his Vision, w: Collected Essays, vol. III, s. 207-209. 
miejsca danego dzieła w porządku artystycznego rozwoju. Koncentrując się na wizualnej postaci dzieł i śledzeniu stylistyczno-formalnych przemian, formalistyczna krytyka pomijała nie tylko kwestie ikonograficznych odniesień i treści, ale ostatecznie redukowała także poczucie wyjątkowości dzieła i jego sens jako konkretnego działania czy gestu.

Pojęcie gestu w kontekście abstrakcyjnego ekspresjonizmu, do którego wciąż tutaj wracamy, kojarzy się przede wszystkim z gestem malarskim i artystą tańczącym nad swoim obrazem. W tym miejscu mam jednak na myśli inaczej rozumiany gest, związany z ekspresją słowa. Choć wiele obrazów pozostawiano bez tytułów, często też nadawano im tytuły celowo enigmatyczne, ujawniające charakterystyczną dla abstrakcyjnego ekspresjonizmu nieufność wobec języka, obawę przed pojęciowymi kliszami². Tytuły te nie tyle wskazywały zawarte w obrazach znaczenia, co w analogii do ich kompozycyjnej struktury, działały poprzez warstwę brzmieniową i skojarzeniową jako na wpół samodzielny werbalny artefakt. Niekiedy, jak na przykład Full fathom five Jacksona Pollocka, prócz brzmieniowych jakości niosły ze sobą krąg literackich, intertekstualnych odniesien. Pollock, sięgając po tytuły z Joyce'a, znajdował w nich odpowiedniość między magmą słów, sugestywnych brzmieniowo, niosących rozliczne, zmysłowe i symboliczne znaczenia - a malarską "bezforemnością” swoich obrazów³ ${ }^{33}$ Z kolei zwięzłe, biblijne tytuły Newmana (Genesis, Adam, Przymierze) czy te przyjmujące postać wezwania $(B e)$ podpowiadały właściwy rejestr odbioru, sugerując, że w oddziaływaniu abstrakcyjnych form zawarty jest głębszy, niewyrażalny temat. Pominięcie tych tytułów oznaczałoby radykalną zmianę i zawężenie sytuacji odbiorczej, jaką one współtworzą. Nie tylko tutaj, ale także w przypadku bardziej prozaicznych i minimalistycznie konkretnych tytułów Stelli, traci się wówczas z pola uwagi wielowymiarowy i wielomedialny charakter tych dzieł.

Upominanie się o malarskie tytuły nie zakłada, że należy w nich szukać uprzywilejowanych śladów twórczej intencji czy swoistej instrukcji obsługi - nie chodzi o traktowanie imion własnych jako prostego wyjaśnienia załączonego do dziel ${ }^{34}$. Tytuły pozostają często elementem przygodnym, mogą

A. Gibson Abstract Expressionism's Evasion of Language , „Art Journal” 1988 Vol. 47, No. 3.

Zob. E. Firestone James Joyce and the First Generation New York School, w: Reading Abstract Expressionism. Context and Critique, ed. by E. Landau, Yale University Press, New Haven-London 2005, S. 403-404.

Por. R. Krauss Wimię Picassa, w: tejże Oryginalność awangardy i inne mity modernistyczne, przeł. M. Szuba, słowo/obraz terytoria, Gdańsk 2011, s. 36-39. 
być fałszywym tropem. Od czasów sztuki konceptualnej przywykliśmy jednak do tego, że język może być tworzywem sztuk plastycznych, aktywnie powiązanym z obrazem, miejscem i czasem. Wydaje się, że podobna sytuacja zachodziła i wcześniej, wówczas gdy tytuły nadawane były ze świadomością językowego gestu, gdy zaznaczały własną obecność i nieprzezroczystość, zamiast wskazywać tylko zawarty w obrazie przedstawieniowy lub alegoryczny sens. Przywołane tu tytuły Franka Stelli mają różny charakter, zwracają uwagę przez cechujący je efekt obcości, ale budzą też niepewność co do właściwego poziomu ich odczytania. Czy powinno się je traktować jako oderwane, przemienione w abstrakcje nazwy, służące identyfikowaniu obrazów i wywołujące jedynie niejasne skojarzenia ze względu na brzmienie - jak na Harran, Madinat-as-Salam, Agbatana, Stinjerli, które odsyłają do arabskich miast - czy też kryje się w nich jakiś głębszy kulturowy i historyczny sens. Czy tytuły te odsyłają do innych, odległych lokalizacji, czy w samych obrazach powinniśmy szukać czegoś, co jest pochodną, śladem tych miejsc? Używając toponimicznych tytułów, Stella prowadzi złożoną grę z pojęciem miejsca, swojego i nie-swojego, obecnego i nieobecnego. Powiedziałabym, że jest to gra równie istotna, jak wielokrotnie podkreślana przez formalistyczną krytykę „fenomenologiczną subtelność i złożoność" jego prac ${ }^{35}$. W swoich konstrukcjach Stella znosi opozycję figury i tła, formy negatywowej i pozytywowej, uzyskując poczucie równoważności i relacyjności elementów, sprzężonych ze sobą, ale nie podporządkowanych z góry danemu centrum ${ }^{36}$. Tytuły podpowiadają, że owa logika bez-centrum sięga jeszcze dalej, że elementy te są także echem czegoś więcej, określonych pejzaży, budowli, barw i obrazów. W Polskich miasteczkach ostrokątne, geometryczne kształty płaszczyzn mogą się wizualnie kojarzyć z konstruktywizmem, suprematyzmem - przypominać o zaprzepaszczonych artystycznych utopiach, jak też o architektonicznych konstrukcjach żydowskich synagog i o ich budowniczych. To, że historie początków nowoczesnej abstrakcji toczyły się na tym samym obszarze Europy Wschodniej gdzie wówczas jeszcze istniały owe miasteczka, nie jest tu bez znaczenia. Dostrzeżenie tych związków i analogii polega jednak na uruchomieniu skojarzeń, do których same tytuły nie dają bezpośredniego klucza. Toponimy użyte przez Stellę nie są dość silnymi miejscami pamięci - po

M. Fried Three American Painters: Noland, Olitsky, Stella, w: Art and Objecthood, s. 223.

Ch. Altieri Frank Stella and Jacques Derrida: Towards a Postmodern Ethics of Singularity, w: Deconstruction and the Visual Arts. Art, Media, Architecture, ed. by P. Brunette, D. Wills, Cambidge University Press, Cambridge 1994, s. 170. 
to żeby pamięć tych imion otworzyć i ponownie ożywić, trzeba ponownie szukać przewodnika w samych obrazach i we własnej pamięci. Być może zresztą, zarówno w odniesieniu do obrazów jak ich tytułów lepiej w ogóle „zrezygnować z metafory przewodnika"37

\section{Abstract}

\section{Agnieszka Rejniak-Majewska}

UNIVERSITY OF ŁÓDŹ

Idioms of Universalism and Proper Names: Frank Stella and American Formalism

This article tackles the role of titles in abstract art and their status as verbal artefacts that have their own referential, intertextual and sonic meaning. Focusing on series of paintings by the American artist Frank Stella, Rejniak-Majewska examines their changing reception and the reasons why early Formalist interpretations of the paintings completely ignored their titles. As much as a critical perspective reveals Formalism's factual, historical situatedness behind its universalist assumptions, the demand to recognize the active role of titles is not an attempt to identify an intention behind the work, but it encourages us to treat titles as a gesture, to acknowledge their poetics and the specificity of the references they construct.

\section{Keywords}

visuality, American formalism, place, title, Frank Stella

37 H. Adams Titles, Titling, and Entitlement to, "The Journal of Aesthetics and Art Ctiticism" 1987 Vol. 46, No. 1, s. 12. 